\title{
Discussion on Teaching Method Reform of Exhibition Designing Curriculum in Colleges
}

\author{
Rui Cheng \\ Shanghai Technical Institute of Electronics and Information, Shanghai 201411, China
}

Keywords: Colleges, Exhibition designing, Curriculum, Teaching method reform

\begin{abstract}
China's exhibition industry has been gradually entering mature stage, the teaching method of exhibition designing in colleges exists imperfections, resulting in students fail to grasp the essence of the profession, thereby affecting the quality of teaching of exhibition designing. In order to cultivate more and more exhibition designing talents with strong professional quality and comprehensive ability, colleges must reform the teaching method of curriculum to clarify teaching ideas. Therefore, this paper conducts study on the teaching method reform of exhibition design curriculum, and put forward specific measures of reform, to provide a reference for the improvement of exhibition design curriculum teaching quality.
\end{abstract}

\section{Introduction}

Throughout the 2008 Beijing Olympic Games and 2011 Shenzhen Universiade embody China's exhibition industry is in a stage of rapid development. Expand the exhibition market for social and economic growth has laid a good foundation, present, China's annual growth rate of nearly 20 percent MICE market, the opening of a series of exhibition fully reflects the prosperity of the country, and the exhibition industry to standardization, scale development. Therefore, the state need a large number of exhibition design talent, then education exhibition design professional settings have higher requirements, exhibition design curriculum by improving teaching methods, thus achieving education and exhibition industry to better docking. Universities during the exhibition design teaching process, teaching must be clear goals and meet the needs of the community, but the current exhibition design curriculum teaching method has limitations, resulting in students fail to adapt to the exhibition industry. Therefore, the university must be reformed to exhibition design curriculum teaching methods, in order to fully enhance the students' comprehensive ability exhibition design.

\section{Requirements for college conducts exhibition designing teaching}

Exhibition design is a profession that trains exhibition design and practical ability, for example, Harbin University of Commerce sets up the profession, through the joint efforts of teachers and students, has session's graduates entering the exhibition industry, and by participating in the practice, has accumulated some experience. However, feedback from the employer can understand, college exhibition design teaching should be improved, and comprehensive ability of graduates and employers demand there is a gap, so community colleges and universities in order to cultivate practical ability of exhibition design talent, We must put forward higher requirements for the exhibition design teaching to meet the needs of society. So, from the exhibition industry and educational characteristics of exhibition design courses teaching universities made the following main points: first, training with professionalism and overall ability of talent. Universities in developing the exhibition design curriculum teaching process, we must improve all aspects of teaching, a reasonable set of courses and provide students with the opportunity to practice, so that students theoretical knowledge and practical closely linked, and then for the exhibition industry has a more profound recognition art. For example, the University of Electronic Science and Technology Exhibition opened in Economics and Management is for students to broaden the development direction, provide a favorable basis to enhance their comprehensive ability. Second, students of business skills. Universities during the exhibition design curriculum teaching process, not only a 
wealth of theoretical knowledge imparted to students, but also to develop their business skills as the main objective. Therefore, it should offer more practical courses, improve all aspects of teaching, students receive theoretical knowledge at the same time, have certain skills, and thus meet the needs of the exhibition industry.

\section{The effect of reform on college exhibition designing curriculum teaching method}

With the country's economic strength has been constantly increasing, for the development of exhibition industry provides a strong guarantee. Exhibition industry in order to have greater progress, and contribute to the modernization of the country, must have more exhibition design talent, so major universities responsibilities. Currently, colleges and universities during the exhibition design teaching process, the teaching method is not perfect, the use of traditional teaching methods Course exhibition design, resulting in overall quality of students has not been effectively improved. Therefore, in order to promote the exhibition design students have better development, universities must be on exhibition design curriculum teaching methods reform, enhance the overall quality of students, and then more quickly adapt to the MICE industry requirements. So, the university curriculum for teaching reform exhibition design exhibition design talent of culture plays an important role. Meanwhile, in the perfect teaching mode, students can design expertise to the exhibition have a deep understanding, and through participation in social practice, to design an excellent exhibition work has laid a good foundation. With the continuous improvement of living standards, people's level of exhibition design and its appreciation has further requirements. However, traditional teaching methods have been difficult to meet the needs of the community, university education in order to develop coordinated and exhibition industry, the need for the exhibition design teaching methods reform, thus laying a solid foundation for the development of exhibition industry.

\section{Status quo of exhibition design teaching in college}

\section{Curriculum provision is not reasonable}

At present, Chinese universities in the exhibition design curriculum teaching, teaching system is imperfect, especially unreasonable curriculum, teaching effect is not good cause. For example, the creation of specialized courses in universities exhibition design sketch, color, composition design, exhibition design, three-dimensional computer design, architecture and interior design basis, etc., and for the design, usability engineering, human-computer interface design layer interaction with the international less of the curriculum, and even some universities have not set up such courses, so students learn curriculum unreasonable, its exhibition design and international level there is a large gap, making the exhibition design teaching in a passive state student exhibition design capabilities, there are a lot less [1]. At the same time, colleges and universities for the exhibition design professional orientation is not accurate, the curriculum process, the primary and secondary curriculum failed to have a clear distinction between cause problems exhibition design teaching.

\section{Lack of practical teaching}

In the process colleges' teaching of exhibition designing, the teaching method is still a big problem. For example, teachers in teaching the completion of the exhibition design, a large amount of time and energy on teaching theoretical knowledge, but relatively few practical teaching, leading exhibition design students have comprehensive knowledge of cognition. Exhibition design as a very practical profession, if universities do not provide sufficient opportunities for students to practice, will result in the student not to have learned the theoretical knowledge and practical closely linked, resulting in exhibition design curriculum teaching effect is not good. If the student the opportunity to participate in the practice less, will result in the actual design skills lacking, once entered the exhibition industry, it will be difficult to meet industry requirements, on the future development of students unfavorable. 
Therefore, since the teaching method imbalances, exhibition design capability will lead to limitations.

\section{School-enterprise cooperation is insufficient}

Currently, for the country to have better development, universities must develop a comprehensive exhibition design talents with the ability, not only qualified companies can work faster, but also to promote the exhibition industry and lay a solid foundation. However, the current university teaching during the exhibition design process, there is still deficiencies. For example, lack of school-enterprise cooperation efforts, the cause of this situation the following aspects: first, universities and enterprises to cooperate believe, will lead to enhanced complexity of teaching, but also to establish close relationships with business, will result in teaching difficulties increased. Exhibition Design is a practical strong discipline, if cooperation with enterprises, in the teaching process takes more time and energy [2]. At the same time, awareness of some universities to school-enterprise cooperation is not strong, then lead the student fails to learn knowledge and practical closely linked. Second, companies are reluctant to accept students to practice. Because companies already have more need is the ability of exhibition design talent, and do not want to spend money and time in culture on exhibition design student, and cause Exhibition Design Course with expectations, there is still a lot of gaps.

\section{Faculty is insufficient}

In the process colleges to cultivate exhibition design talents, they need to regard cultivating international exhibition design talents as the goal of teaching, in order to achieve social train highly qualified personnel and comprehensive ability. However, since the exhibition design is a discipline of science and technology with art. For example, the exhibition design teachers have a strong art conservation, but also to achieve proficiency in the use of computers, especially the use of two-dimensional, three-dimensional computer technology deal with color, print and pattern, etc., in such a complex teaching requirements, not all teachers exhibition design We are able to achieve mastery of the effect. Therefore, the university in order to further improve teaching quality exhibition design, the need to increase capital investment, and thus growth of teachers. However, some colleges and universities because they have failed to fully cognitive, but also cannot promote faculty as a measure of the exhibition design curriculum reform of teaching methods, resulting in low levels of the comprehensive education of teachers, so lack of student mastery of professional and exhibition design capability has limitations.

\section{Measures to reform college exhibition designing teaching methods reform}

\section{Complete teaching model}

A college aims to link education and exhibition industry, must reform the exhibition design curriculum teaching methods, by improving the teaching mode to cultivate the exhibition design talents with comprehensive capabilities. For example, in the "color sketch modeling foundation," the teaching process, teachers will be teaching traditional teaching methods with the driving mode to be closely linked, so that students in the pattern of sound teaching learning to rich exhibition expertise. Teachers use modern multimedia to students about the sketch elements contain point, line, surface, and then to explain the type of perspective, under normal circumstances, the perspective is divided into three types, respectively for the parallel perspective, angled perspective and scattered perspective [3]. For angled perspective, the perspective is two o'clock, mainly object to the eye level of a two o'clock disappear, specifically shown in Figure 1. Teachers by performing exhibition design in the driving mode that allows students to have a comprehensive knowledge of the exhibition design awareness, so as to enhance students' ability to play an important role in exhibition design. 


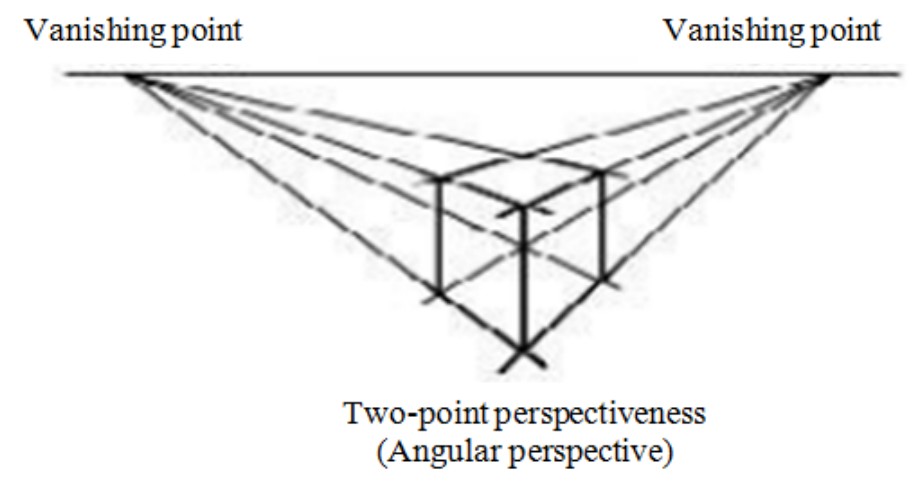

Fig. 1 Angular perspective (two-point perspectiveness)

\section{Improve students' quality beyond paint brush}

Exhibition design is a cross with other disciplines have discipline, but the specialty students have high artistic quality requirements, so colleges and universities in order to improve the quality of teaching exhibition design for the community to train more and more exhibition design artistic talents brush the outer qualities necessary to enhance the students as an important content. So, teaching in the teaching process, not just the teaching content to teach students, and let students into nature and life, so as students specializing in exhibition design drawings, sketches and other courses have a more profound understanding. For example, in the teaching process, we must cultivate the students 'ability to hand-drawn and computer painting, and thus enhance students' artistic accomplishment, to enable students to learn professional exhibition design process, to have a comprehensive grasp of the various knowledge points. Teachers in the teaching process, the need for students to teach painting techniques, objects by decomposition, to analyze its internal, and then to observe changes in the various parts of an object from different angles. For example, a leaf from a different point of view to appreciation, through creativity and imagination to paint, and ultimately the quality of the brush outside the effective culture [4]. Thus, an important way to enhance the brush outside literacy training exhibition design talents of students.

\section{Scientifically set teaching curriculum}

In the process that colleges and universities conduct exhibition designing teaching methods reform, we must set up scientific curriculum, teachers conducted in accordance with the order of the exhibition design teaching, and then let students have a hierarchy. Teachers should be clear of professional exhibition design foundation course order should be design sketch, design basis, composition and a two-dimensional plane, three-dimensional computer technology. Students at a reasonable order of learning, thereby learning much easier. Such teachers can constitute first master of color and plane, etc., and then through software practice arrays, mirroring, mutation, etc., to enhance students' interest in learning the exhibition set up the course, and then the exhibition design is conducive to enhancing the quality of teaching [5]. Therefore, the university set up the exhibition in curriculum design process, we must adhere to the principle of easy to difficult, and set some courses have practical value, thereby contributing to the development exhibition design teaching.

\section{Increase faculty resources}

Colleges and universities in order to improve teaching quality exhibition design, exhibition design for the society to cultivate talents with comprehensive ability, in order to facilitate the reform of teaching, teachers must increase, and thus lay a solid foundation for student learning. Universities must increase capital investment, part of the funds will be used to attract teachers with advanced teaching experience, because under the guidance of an experienced teacher, students can have a more thorough exhibition design professional understanding. At the same time, colleges and universities should make the exhibition design professional teacher training, to broaden their knowledge and thus 
respond to the challenges of teaching. In short, the exhibition design colleges and universities in order to carry out the reform of teaching methods courses, teachers must be increased so as to provide a favorable guarantee for student learning.

\section{Conclusions}

Exhibition designing profession is very practical. In the process of exhibition planning in society, it requires exhibition designers have a certain professionalism, combined with the specific situation, to design the works meet the specifications. Therefore, colleges should intensify exhibition design teaching methods reform, and then to train exhibition design talents adapt to exhibition industry.

\section{References}

[1] Liu Qin. First exploration of teaching method of exhibition designing curriculum in non-artistic colleges. Jinshan,2011(3):139-140.

[2] Wen Ling. "Exhibition space design" course teaching reform. Beauty(Mid Episode)· Journal of fine arts, 2015(4):62-63.

[3] Zhou Jiahui. Discussion on exhibition designing curriculum teaching model based on market demands. Intelligence, 2013(12):195-195.

[4] An Xiaobo, Wang Zeye. Discussion on the displacement of teaching focus of college exhibition designing profession from Shanghai Expo. Master, 2010(13):51-52.

[5] Lu Xiaohong, Zhao Xin. Discussion on college exhibition designing talent cultivation model in market context. Popular literature, 2012(1):284-285. 